\title{
Penicillin levels in sputum
}

\author{
F. F. HAFEZ, ${ }^{1}$ SHEILA M. STEWART , ${ }^{2}$ AND M. EILEEN BURNET \\ From the Department of Respiratory Diseases, University of Edinburgh
}

The levels achieved in the sputum by the systemic administration of penicillin have attracted little attention. There are relatively few publications on this subject. The present investigation was designed to find an answer to the following questions:

1. What levels are achieved in the sputum by the systemic administration of penicillin?

2. Does the sputum penicillin level correlate with the serum level ?

3. Are the sputum levels conditioned by the pathological condition under treatment ?

4. Does the sputum level vary from one stage to another of the disease?

5. What is the effect on the sputum penicillin level of the presence of penicillinase-producing bacteria?

6. To what extent is the sensitivity of the bacterial population of the sputum related to the presence of an antibiotic?

\section{PATIENTS INVESTIGATED}

Thirty-four patients were investigated, 27 men and 7 women; their ages ranged from 37 to 81 years. They included cases of pneumonia, bronchitis with acute exacerbation, bronchial neoplasm, spontaneous pneumothorax, and pulmonary infarction. All were in hospital throughout the period of investigation.

\section{METHODS}

CHEMOTHERAPY In order to ensure the exact timing and dosage of the drugs given, all therapy was administered by one of us (F. F. H.). The actual treatment given was decided by the clinician in charge of the case.

The treatment groups were as follows:

\section{Group A : Penicillin}

Benzyl penicillin, 1 mega unit twice daily intramuscularly (11 patients).

1 Present address: Air Force Hospital, Cairo, U.A.R. 2 Royal Victoria Hospital Tuberculosis Trust Research Fellow
Benzyl penicillin, 2 mega units twice daily intramuscularly (3 patients).

\section{Group B : Penicillin plus streptomycin}

Benzyl penicillin, 1 mega unit, and streptomycin, 0.5 to $1 \mathrm{~g}$., both twice daily intramuscularly (18 patients).

Benzyl penicillin, 2 mega units, and streptomycin, $0.5 \mathrm{~g}$., both twice daily intramuscularly (1 patient).

Benzyl penicillin, 3 mega units, and streptomycin, 1 g., both twice daily intramuscularly (1 patient).

In 11 of the patients who received penicillin plus streptomycin during the first week, streptomycin was stopped and penicillin continued alone in the second week.

SPECIMENS FOR ASSAY Sputum is often heterogeneous in nature and may be partially purulent and partially mucoid. It is therefore difficult to differentiate between a true mucopurulent sputum and a purulent sputum contaminated with saliva. Since saliva may contain appreciable concentrations of penicillin, assays of drug concentrations in saliva were made in parallel with those in the sputum in order to determine whether the apparent sputum levels could be due to the presence of saliva in the specimen.

All specimens were collected by the person giving the drug and were sent to the laboratory within two hours of collection.

Pre-treatment specimens It was not possible to collect specimens for assay from patients in the investigation before the start of treatment. Assay results were, however, available on 18 specimens of sputum and serum collected from 18 other patients before the start of antibiotic therapy.

Post-treatment specimens Specimens of sputa and sera were collected from three patients at hourly intervals after the intramuscular administration of 2 or 3 mega units of benzyl penicillin 
in order to establish the time at which the peak sputum level was reached. The maximum levels were obtained between two and three hours after injection. Therefore for the main investigation sputum specimens were collected at two and three hours.

One set of specimens was collected on the second, third, fourth, or fifth day after the start of treatment, and a second set one week later on the ninth, tenth, eleventh, or twelfth day.

Serum and saliva were collested two hours after the dose of antibotic.

Immediately after the administration of the drugs the patient was requested to cough. All sputum produced at this time was discarded. Specimens for assay were collected two and three hours after the dose.

BaCTERIOLOGiCAL METHOdS A cup diffusion method, similar to that recommended by Heathcote and Nassau (1951). was used for penicillin assay. A peptone yeast extract agar was melted and cooled to $50^{\circ} \mathrm{C}$. To $200 \mathrm{ml}$. of agar was added $4 \mathrm{ml}$. of a 48-hr. nutrient broth culture of Sarcina lutea which had previously been made resistant in vitro to $200 \mu \mathrm{g}$. streptomycin per ml. After thorough mixing, $20 \mathrm{ml}$. quantities were pipetted into sterile $11 \mathrm{~cm}$. petri dishes. The plates were dried at $37^{\circ} \mathrm{C}$. Four cups were then cut in each plate using a metal cork borer of $8 \mathrm{~mm}$. diameter. Of the fluid under test, $0.06 \mathrm{ml}$. was placed into each of two cups. The plates were incubated at $37^{\circ} \mathrm{C}$. for 48 hours.

Test fluids The following were used.

Assays were carried out on neat serum and on 1 in 10 and 1 in 100 dilutions made in sterile distilled water.

Sputum was homogenized by shaking mechanically with an equal volume of distilled water and four glass beads. The neat homogenate was used for the assay.

Neat saliva was used for the assay.

Standard solutions of penicillin The following range of penicillin solutions was used: $1 \cdot 0,0 \cdot 5,0 \cdot 25$, $0 \cdot 12$, and 0.06 units $/ \mathrm{ml}$. in distilled water. Each standard penicillin concentration was also put up in duplicate. The standard solutions were included with each batch of tests.

A standard curve was prepared from the means of the pairs of readings obtained for the zones of inhibition for each of the standard penicillin concentrations. From the means of the two readings for the test fluids, the penicillin concentrations were read off the curve, using the dilutions of the test fluid giving a zone of inhibition falling within the range of those of the standard solutions. The final concentration was calculated, allowing for dilution. if any.

Routine culture and sensitivity tests All speci- mens of sputa were cultured on blood agar and boiled-blood agar plates. Tests for sensitivity to penicillin, using the filter paper disc method, were done on all strains of Haemophilus influenzae, Streptococcus pneumoniae, Staphylococcus pyogenes, Klebsiella pneumoniae, and Escherichia coli isolated.

Tests for penicillinase-producing organisms All specimens of sputum and saliva were inoculated into tubes of nutrient broth and incubated overnight. Nutrient agar in $10 \mathrm{ml}$. quantities was melted. cooled to $50^{\circ} \mathrm{C}$., and inoculated with $0.02 \mathrm{ml}$. of an 18 -hour broth culture of the Oxford H. strain of Staph. pyogenes. After mixing, the agar was poured into 11 $\mathrm{cm}$. petri dishes and the plates were dried at $37^{\circ} \mathrm{C}$. Three cups, $6 \mathrm{~mm}$. in diameter, were cut in each plate. The cups were filled as follows:

(1) $0.02 \mathrm{ml}$. of the supernatant of the nutrient broth culture, plus $0.02 \mathrm{ml}$. of a $1 \cdot 0 \mathrm{unit} / \mathrm{ml}$. penicillin solution

(2) $0.02 \mathrm{ml}$. of the $1.0 \mathrm{unit} / \mathrm{ml}$. solution of penicillin plus $0.02 \mathrm{ml}$. of sterile distilled water

(3) $0.02 \mathrm{ml}$. of the broth supernatant plus $0.02 \mathrm{ml}$. sterile distilled water

After incubation at $37^{\circ} \mathrm{C}$. for 18 hours, the zones of inhibition were measured. The results were graded as follows:

Maximal activity: There was no inhibition around the cup containing both the supernatant fluid and the penicillin solution.

Partial activity: The zone of inhibition around the cup containing the supernatant plus penicillin was at least $3 \mathrm{~mm}$. less than that around the cup containing penicillin only.

No activity: The zone around the cup containing the supernatant plus penicillin was equal to or only 1 or $2 \mathrm{~mm}$. less than that around the cup containing penicillin and water.

If there was a zone of inhibition around the cup containing the supernatant and water, the test was considered to be invalidated.

\section{RESULTS}

Specimens of sputum and serum were tested from 18 patients before the start of antibiotic therapy in hospital. In 17 there was no zone of inhibition with either the sputum or serum. In the remaining patient there was a level of less than 0.12 unit penicillin per $\mathrm{ml}$. in the sputum and of 1.0 unit per $\mathrm{ml}$. in the serum. It was subsequently found that this patient had received an injection of penicillin immediately before admission to hospital.

From these results, therefore, there was no evidence of the presence in sputum of substances other than antibiotics which might cause nonspecific inhibition in the cup-diffusion assay technique used. 
PENICILLIN LEVELS IN THE SPUTUM

Comparison of levels in patients receiving penicillin alone and in those receiving penicillin plus streptomycin Thirty sputum specimens were assayed from 11 patients receiving 1 mega unit of penicillin twice daily and compared with 21 specimens from 18 patients receiving the same dose of penicillin together with streptomycin, 0.5 to $1 \mathrm{~g}$. twice daily. A comparison of the sputum levels in these two groups of patients showed that the addition of streptomycin did not significantly affect the level of penicillin $\left(\chi^{2}=\right.$ 0.51 ). Indeed, there was no suggestion of any difference. Similarly, no difference was found between the groups in the other analyses. The assay results on specimens from these two groups of patients have therefore been combined.

Comparison of second and third hour sputum levels Table I shows a comparison of the levels in sputum two and three hours after the start of treatment. There is a good correlation between the second and third hour levels $(P<0.001)$.

Comparison of sputum and serum levels The correlation between the serum levels and the second and third hour sputum levels is shown in Table II and Figure 1. The results for the two treatment groups have been combined, since there was no difference between the individual series $(P<0 \cdot 8>0 \cdot 7)$.

FIG. 1. Comparison of penicillin levels in serum and sputum after intramuscular injection of penicillin.
TABLE I

COMPARISON OF SPUTUM LEVEIS 2 AND 3 HOURS AFTER INJECTION OF 1 MEGA UNIT PENICILLIN

\begin{tabular}{|c|c|c|c|c|c|c|}
\hline \multirow{2}{*}{$\begin{array}{c}\text { Second } \\
\text { Hour } \\
\text { Sputum } \\
\text { Level } \\
\text { (units } \\
\text { ml.) }\end{array}$} & \multicolumn{5}{|c|}{ Third Hour Sputum Level (units/ml.) } & \multirow{2}{*}{ Totals } \\
\hline & Nil & $<0.12$ & $\begin{array}{c}0.12- \\
0.24\end{array}$ & $\begin{array}{c}0.25- \\
0.5\end{array}$ & $>0.5$ & \\
\hline $\begin{array}{c}\text { Nil } \\
<0 \cdot 12 \\
0 \cdot 12-0.24 \\
0.25-0.5 \\
>0.5\end{array}$ & $\begin{array}{l}3 \\
0 \\
1 \\
3 \\
0\end{array}$ & $\begin{array}{l}1 \\
4 \\
3 \\
0 \\
1\end{array}$ & $\begin{array}{l}4 \\
3 \\
8 \\
2 \\
1\end{array}$ & $\begin{array}{l}1 \\
1 \\
4 \\
6 \\
3\end{array}$ & $\begin{array}{l}0 \\
0 \\
0 \\
1 \\
1\end{array}$ & $\begin{array}{r}9 \\
8 \\
16 \\
12 \\
6\end{array}$ \\
\hline Totals & 7 & 9 & 18 & 15 & 2 & 51 \\
\hline
\end{tabular}

TABLE II

COMPARISON OF LEVEIS IN SPUTUM AND SERUM AFTER 1 MEGA UNIT PENICILIIN

\begin{tabular}{|c|c|c|c|c|c|c|}
\hline \multirow{2}{*}{$\begin{array}{c}\text { Serum } \\
\text { Level } \\
\text { (units } \\
\text { ml.) }\end{array}$} & \multicolumn{5}{|c|}{ Sputum Level (units ml.) } & \multirow{2}{*}{ Totals } \\
\hline & Nil & $<0 \cdot 12$ & $\begin{array}{c}0.12- \\
0.24\end{array}$ & $\begin{array}{c}0.25- \\
0.5\end{array}$ & $>0.5$ & \\
\hline $\begin{array}{l}1 \cdot 0-3 \cdot 9 \\
4 \cdot 0-7 \cdot 9 \\
8 \cdot 0-16 \cdot 0 \\
>16 \cdot 0\end{array}$ & $\begin{array}{l}2 \\
3 \\
3 \\
7 \\
\end{array}$ & $\begin{array}{l}1 \\
5 \\
9 \\
3\end{array}$ & $\begin{array}{r}2 \\
15 \\
14 \\
7\end{array}$ & $\begin{array}{r}5 \\
6 \\
12 \\
4\end{array}$ & $\begin{array}{l}0 \\
1 \\
2 \\
5\end{array}$ & $\begin{array}{l}10 \\
30 \\
40 \\
26\end{array}$ \\
\hline Total & 15 & 18 & 38 & 27 & 8 & 106 \\
\hline
\end{tabular}

The penicillin concentration in the serum showed a good correlation with that in the sputum $(P<0.001)$ although the sputum levels were appreciably lower. But for any given serum con-

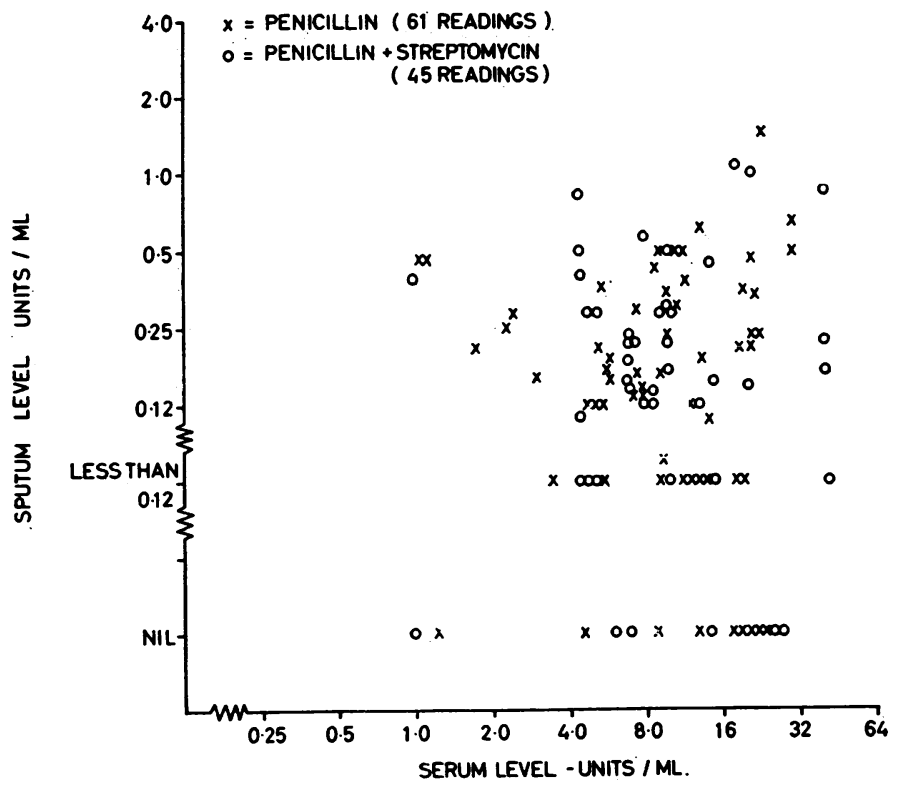


centration there was a considerable scatter in the sputum levels.

There were 22 instances from 16 patients in which the serum level was 8.0 units $/ \mathrm{ml}$. or above and in which at least one of the sputum levels was less than $0.12 \mathrm{unit} / \mathrm{ml}$. In six patients $(12$ specimens) both the second and third hour sputum levels were low. In five patients the second hour sputum level was low but the third hour specimen contained more than 0.12 unit penicillin $/ \mathrm{ml}$. In a further five patients a level of $0.12 \mathrm{unit} / \mathrm{ml}$. or above was present in the second hour specimen but less than 0.12 unit $/ \mathrm{ml}$. was detected in the third hour specimen.

In only two patients was a low sputum level and high serum level found in specimens collected in both the first and the second weeks of therapy.

The low sputum levels associated with high serum levels were not related to the presence of pneumonia as opposed to bronchitis.

Comparison of sputum and saliva levels The comparison of the second hour sputum and saliva levels is shown in Table III and Figure 2. The sputum levels were generally higher than those found in the saliva. This difference occurred in both treatment groups and was statistically significant $(\mathrm{P}<0.001)$.

In 11 cases the saliva level was greater than that found in the sputum. In seven of these no drug was detected in the sputum. In the remaining four
TABLE III

COMPARISON OF SECOND HOUR SPUTUM AND SALIVA LEVELS AFTER 1 MEGA UNIT PENICILLIN

\begin{tabular}{|c|c|c|c|c|c|c|}
\hline \multirow{2}{*}{$\begin{array}{c}\text { Second } \\
\text { Hour } \\
\text { Sputum } \\
\text { Level } \\
\text { (units/ } \\
\text { ml.) }\end{array}$} & \multicolumn{5}{|c|}{ Saliva Level (units/ml.) } & \multirow{2}{*}{ Totals } \\
\hline & Nil & $<0.12$ & $\begin{array}{l}0.12- \\
0.24\end{array}$ & $\begin{array}{c}0.25- \\
0.5\end{array}$ & $>0.5$ & \\
\hline $\begin{array}{c}\text { Nil } \\
<0.12 \\
0.12-0.24 \\
0.25-0.5 \\
>0.5 \\
\end{array}$ & $\begin{array}{l}2 \\
2 \\
5 \\
3 \\
0\end{array}$ & $\begin{array}{l}5 \\
6 \\
6 \\
1 \\
1\end{array}$ & $\begin{array}{l}1 \\
\mathbf{0} \\
\mathbf{6} \\
\mathbf{3} \\
\mathbf{2} \\
\end{array}$ & $\begin{array}{l}1 \\
0 \\
3 \\
1 \\
1 \\
\end{array}$ & $\begin{array}{l}0 \\
0 \\
0 \\
1 \\
1 \\
\end{array}$ & $\begin{array}{r}9 \\
8 \\
20 \\
9 \\
5\end{array}$ \\
\hline Totals & 12 & 19 & 12 & 6 & 2 & 51 \\
\hline
\end{tabular}

cases the apparent penicillin level in the sputum $\overrightarrow{0}$ could have been due to contamination of the $\frac{9}{3}$ sputum with penicillin-containing saliva.

Comparison of second hour sputum levels in first and second weeks of treatment A compari- $\vec{\bullet}$ son of the second hour sputum levels in the first of and second weeks of treatment with 1 mega unit of penicillin twice daily was made to determine whether the antibotic level in the sputum varied with the consecutive stages of the disease. The results are shown in Table IV. There was no difference in the levels of the two groups $(P>0.4$ $<0.5)$.

Relationship between sputum levels and clinical diagnosis Table $\mathrm{V}$ shows the clinical diagnosis

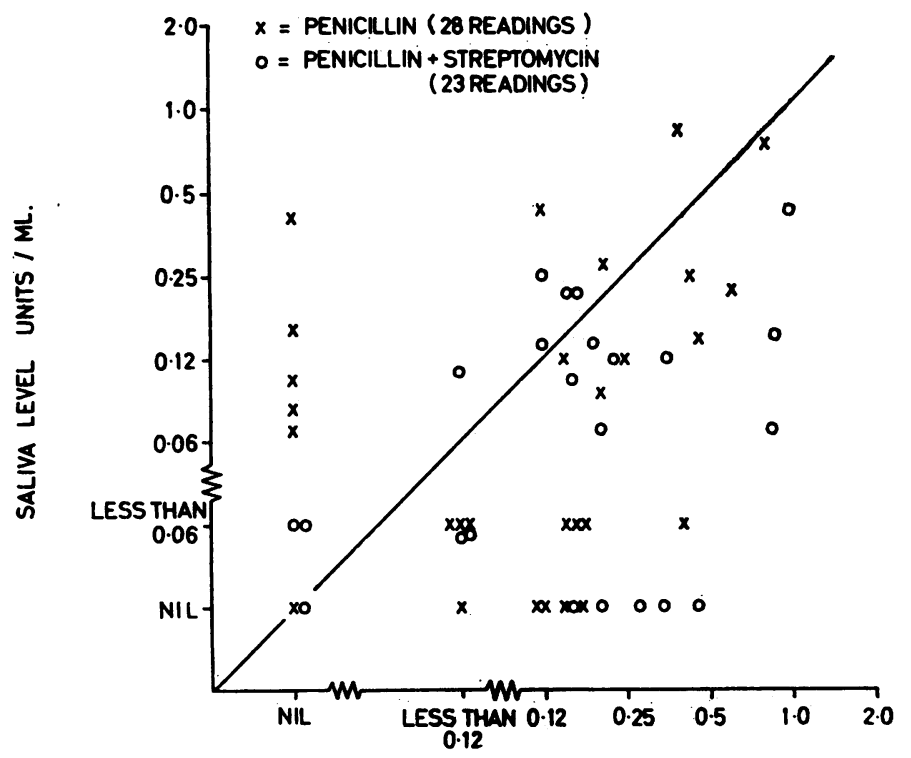

SPUTUM LEVEL-UNITS / ML.
FIG. 2. Comparison of penicillin levels in $\Omega$ sputum and saliva two hours after intra- $N$ muscular injection of 1 mega unit of benzyl $\mathrm{N}$ penicillin (diagonal line represents the $45^{\circ} \mathrm{\omega}$ line). 
TABLE IV

COMPARISON OF SECOND HOUR SPUTUM LEVELS IN FIRST AND SECOND WEEK OF TREATMENT AFTER 1 MEGA UNIT OF PENICILLIN

\begin{tabular}{|c|c|c|c|c|c|c|}
\hline \multirow{2}{*}{$\begin{array}{c}\text { First } \\
\text { Week } \\
\text { Sputum } \\
\text { Level } \\
\text { (units } \\
\text { ml.) }\end{array}$} & \multicolumn{5}{|c|}{ Second Week Sputum Level (units $/ \mathrm{ml}$.) } & \multirow{2}{*}{ Totals } \\
\hline & Nil & $<0 \cdot 12$ & $\begin{array}{c}0.12- \\
0.24\end{array}$ & $\begin{array}{c}0.25 \\
0.5\end{array}$ & $>0.5$ & \\
\hline $\begin{array}{c}\mathrm{Nil} \\
<0.12 \\
0.12-0.24 \\
0.25-0.5 \\
>0.5\end{array}$ & $\begin{array}{l}1 \\
1 \\
1 \\
1 \\
0\end{array}$ & $\begin{array}{l}2 \\
0 \\
2 \\
1 \\
1\end{array}$ & $\begin{array}{l}1 \\
1 \\
4 \\
2 \\
2\end{array}$ & $\begin{array}{l}0 \\
0 \\
0 \\
3 \\
0\end{array}$ & $\begin{array}{l}0 \\
0 \\
2 \\
1 \\
0\end{array}$ & $\begin{array}{l}4 \\
2 \\
9 \\
8 \\
3\end{array}$ \\
\hline Totals & 4 & 6 & 10 & 3 & 3 & 26 \\
\hline
\end{tabular}

T ABLE V

COMPARISON OF PENICILLIN LEVELS IN SPUTUM WITH CLINICAL DIAGNOSIS

\begin{tabular}{|c|c|c|c|c|}
\hline \multirow{2}{*}{$\begin{array}{c}\text { Sputum } \\
\text { Penicillin } \\
\text { Level } \\
\text { (units } / \mathrm{ml} \text {.) }\end{array}$} & \multicolumn{3}{|c|}{ Clinical Diagnosis } & \multirow{2}{*}{ Totals } \\
\hline & Pneumonia & Bronchitis & $\begin{array}{l}\text { Miscel- } \\
\text { laneous }\end{array}$ & \\
\hline $\begin{array}{l}\mathrm{Nil} \\
<0.12 \ldots \\
0.12-0.24 \\
0.25-0.5 \ldots \\
>0.5 \quad \ldots\end{array}$ & $\begin{array}{r}5 \\
9 \\
7 \\
13 \\
4\end{array}$ & $\begin{array}{r}10 \\
12 \\
32 \\
18 \\
7\end{array}$ & $\begin{array}{l}1 \\
1 \\
4 \\
3 \\
2\end{array}$ & $\begin{array}{l}16 \\
22 \\
43 \\
34 \\
13\end{array}$ \\
\hline $\begin{array}{c}\text { Total no. of } \\
\text { specimens } \\
\text { Total no. of } \\
\text { patients }\end{array}$ & $\begin{array}{l}38 \\
10\end{array}$ & $\begin{array}{l}79 \\
21\end{array}$ & $\begin{array}{r}11 \\
3\end{array}$ & $\begin{array}{r}128 \\
34\end{array}$ \\
\hline
\end{tabular}

and the penicillin level in the sputum at both the second and third hour after treatment in the first and second weeks.

It appears from these results that there was no definite relationship between the levels in the sputum and the pathological entity undergoing treatment.

Effect of penicillinase-producing bacteria in the sputum on the sputum level Table VI shows the correlation between the results of tests for penicillinase activity and the level of penicillin in the sputum. The activity of the test-penicillin was completely reversed in 26 of the 135 sputa tested

T A B LE V I

EFFECT ON SPUTUM PENICILLIN LEVEL OF PRESENCE OF PENICILLINASE-PRODUCING BACTERIA

\begin{tabular}{|c|c|c|c|c|c|c|}
\hline \multirow{2}{*}{$\begin{array}{l}\text { Penicil- } \\
\text { linase } \\
\text { Activity } \\
\text { of } \\
\text { Sputum } \\
\text { Culture }\end{array}$} & \multirow{2}{*}{$\begin{array}{l}\text { Total } \\
\text { No. } \\
\text { of } \\
\text { Sputa }\end{array}$} & \multicolumn{4}{|c|}{$\begin{array}{l}\text { Penicillin Level in Sputum } \\
\text { (units'ml.) }\end{array}$} & \multirow{2}{*}{$\begin{array}{c}\text { Sputa } \\
\text { with } \\
0 \cdot 12 \\
\text { unit/ } \\
\text { ml. } \\
\text { or Over } \\
(\%)\end{array}$} \\
\hline & & Nil & $<0.12$ & $\underset{0 \cdot 5}{0.12-}$ & $>0.5$ & \\
\hline $\begin{array}{l}\text { Maximal } \\
\text { Partial . . } \\
\text { Absent } \ldots\end{array}$ & $\begin{array}{l}26 \\
17 \\
92 \\
\end{array}$ & $\begin{array}{r}5 \\
1 \\
10\end{array}$ & $\begin{array}{r}2 \\
2 \\
17\end{array}$ & $\begin{array}{l}16 \\
13 \\
54\end{array}$ & $\begin{array}{r}3 \\
1 \\
11\end{array}$ & $\begin{array}{l}73 \\
82 \\
71\end{array}$ \\
\hline Total & 135 & 16 & 21 & 83 & 15 & 73 \\
\hline
\end{tabular}

and partially reversed in 17 . In the remaining 92 sputa there was no evidence of the presence of penicillinase. In $73 \%$ of the sputa with maximal penicillinase activity there was a penicillin level of $0.12 \mathrm{unit} / \mathrm{ml}$. or above as compared with $71 \%$ in those specimens in which no penicillinase was detected.

It therefore seems that the presence of penicillinase-producing organisms has no effect on the penicillin level in the sputum.

Sputum levels in patients receiving 2 or 3 mega units of penicillin twice daily Four patients received 2 mega units of penicillin twice daily. The mean level in 16 sputa examined from these patients was 0.31 unit $/ \mathrm{ml}$, the range being less than 0.12 to greater than 1.0 unit of penicillin per $\mathrm{ml}$. One patient who received 3 mega units of penicillin twice daily had a constant level of 1.2 units $/ \mathrm{ml}$. in all four sputa tested.

The mean level of 102 sputa from patients receiving 1 mega unit twice daily was 0.24 unit/ $\mathrm{ml}$., the range being nil to 1.6 units $/ \mathrm{ml}$.

Correlation of sputum penicillin levels with incidence of potential pathogens or Esch. coli in the sputa and their resistance to penicillin All of the pathogens or strains of Esch. coli isolated from sputa after the start of treatment were resistant to penicillin. All but three of the sputum specimens from which pathogens or Esch. coli were isolated contained a detectable amount of penicillin.

\section{DISCUSSION}

There have been few reports in the literature of penicillin levels in the sputum after intramuscular administration of the drug. In 1946 Humphrey and Joules found detectable levels in the sputum from eight out of 10 patients with lobar pneumonia who had received a single injection of 15,000 to 100,000 units. In seven other patients with lung abscess, purulent bronchitis or bronchiectasis, little or no drug was found in the sputum. Heathcote and Nassau (1951) reported levels of 0.1 to $0.7 \mathrm{unit} / \mathrm{ml}$. of sputum in three patients two hours after a dose of 1 mega unit.

In 1952 Mulder, Goslings, Van der Plas, and Lopes Cardozo found mean levels of 0.06 to 0.28 unit $/ \mathrm{ml}$. in the sputum from patients with mucopurulent bronchitis receiving 250,000 units penicillin per dose with total daily doses of 1 to 4 mega units. They showed that the higher mean levels were associated with the higher daily dose of penicillin.

Jensen, Lund, and Marner (1962) reported levels 
of 0.4 to 6 units $/ \mathrm{ml}$. of sputum in 14 patients one hour after doses of 5 to 20 mega units. They suggested that there was a correlation between the sputum and serum levels, the sputum being approximately 40 -fold lower, but this correlation was not consistent.

The present investigation was planned to ascertain the levels achieved in the sputum after intramuscular administration of 1 to 3 mega units of benzyl penicillin, and to determine whether there was a correlation between such levels and those found in the serum. The possible effect on the sputum level of the pathological entity under treatment, the stage of the disease (acute as compared with convalescent), and the presence of penicillinase-producing bacteria was also investigated.

Hourly readings on three patients showed that the peak sputum level occurred two to three hours after the injection of penicillin. Sputa for the investigation were therefore collected at these times.

Levels of at least 0.12 unit penicillin per $\mathrm{ml}$. sputum were found in $69(68 \%)$ of the 102 spesimens tested from 29 patients receiving 1 mega unit of penicillin per dose ; in 35 of these 69 specimens the level was at least $0 \cdot 25 \mathrm{unit} / \mathrm{ml}$. Traces of the drug were found in a further $16 \%$ of the 102 specimens but the levels were too low for accurate assay.

All but one of the 16 sputum specimens from the patients who received 2 mega units of penicillin per dose had levels of at least $0 \cdot 12$ unit/ ml. ; the remaining one contained less than 0.12 unit $/ \mathrm{ml}$. All of the four sputum specimens examined from the one patient receiving 3 mega units per dose contained $1 \cdot 2$ units penicillin per ml.

The mean sputum level in the 102 specimens from patients receiving 1 mega unit penicillin per dose was 0.24 unit $/ \mathrm{ml}$. as compared with a mean of $0.31 \mathrm{unit} / \mathrm{ml}$. for the 16 specimens from four patients receiving 2 mega units, and 1.2 units $/ \mathrm{ml}$. for one patient receiving 3 mega units per dose.

Penicillin was therefore shown to penetrate into the sputum in patients treated with these doses. There is a suggestion that higher levels are obtained with the higher doses, but the number of patients was small. The absence of penicillin was mainly a random finding. In only three patients was no drug detected in the sputum on more than one ozcasion. All three were receiving 1 mega unit of penicillin per dose. In no patient was there no detectable drug in any of the four sputum specimens examined.
There was no difference between the levels in the sputa collected two hours after the dose as compared with that collected one hour later. Sputa from patients treated with streptomycin in addition to the penicillin, 1 mega unit twice daily, showed the same range of levels as those from patients treated with penicillin alone.

There was a statistical correlation between the sputum and serum levels, but for any given concentration in the serum there was a considerable scatter in the sputum levels.

The sputum drug level might be expected to be affected by the degree of inflammation of the infected tissues. With greater inflammation, such as may occur in the earlier stages of the disease and in pneumonia as compared with bronchitis, the increased blood supply might result in a greater diffusion of the drug into the tissue fluids and therefore higher sputum levels. A comparison of the sputum levels in patients with pneumonia and bronchitis and in sputa collected in the first and second weeks of treatment did not suggest that these factors play a part in determining the sputum level of the drug. It should, however, be noted, in relation to the stage of the disease, that some of the patients in the investigation had previously received therapy before their admission to hospital ; moreover, some of the first week specimens were not collected until the fourth or fifth day of treatment when the more acute phase of the infection may have passed.

A number of bacteria isolated from sputum produce penicillinase. It was considered possible that the presence of such organisms may result in the inactivation of the penicillin, but a comparison of the sputum penicillin level with the penicillinase activity of cultures from the sputum did not show any reduction of the penicillin level in those from which penicillinase-producing bacteria were isolated. The presence of such organisms does not therefore seem to affect the penicillin activity in the sputa.

The relatively high doses of penicillin used in this investigation, resulting in detectable levels of penicillin being present in a majority of the sputum specimens examined, presumably contributed to the fact that no pathogens sensitive to penicillin were isolated after the start of treatment in any case. It was not therefore possible to make any correlations between the incidence of such organisms and the level of the drug in the sputum.

The results of this investigation suggest that in the treatment of respiratory infections, where the causative organism may be $H$. influenzae, an organism of known resistance to low concentra- 
tions of penicillin, the use of higher doses of the drug may result in better clinical response. This has in fact been shown to be the case in the treatment of acute exacerbations of chronic bronchitis (Lewis and Pines, 1965). In a controlled trial, the results of treatment with penicillin, in doses of 3 mega units twice daily, were statistically superior to those with penicillin, 1 mega unit, plus streptomycin, $0.5 \mathrm{~g}$., both twice daily.

\section{SUMMARY}

Penicillin levels were estimated in sputa and sera from 34 patients receiving 1 to 3 mega units of benzyl penicillin intramuscularly twice daily.

Hourly assays on three patients showed that the peak sputum level was reached between the second and third hour after injection. Sputum was collected at both these times in the main investigation.

A comparison of 51 pairs of second and third hour sputum specimens showed no difference in the range of penicillin concentration at the two times. Nor was there any difference in the penicillin sputum levels in 11 patients treated with penicillin alone, 1 mega unit twice daily, as compared to the levels in sputum from 18 patients treated with penicillin, 1 mega unit, plus streptomycin, 0.5 g., both twice daily.

In all but three of the 34 patients there was a detectable level of penicillin in all but one of the sputa examined. In the remaining three patients two out of four specimens contained no detectable penicillin.

Assays of penicillin in the saliva were carried out concurrently with those in the sputum. In all but four specimens the sputum level was either higher than that in the saliva or the sputum contained no detectable drug. There was therefore no evidence in these cases that the sputum level could be attributed to contamination of the specimen with saliva. In the remaining four specimens the level of the drug was higher in the saliva than in the sputum, and therefore the apparent sputum level could have been due to contamination of the sputum specimen with drug-containing saliva.

On the whole, the penicillin concentration in the sputum paralleled that in the serum, though at a much lower level. But for any given serum concentration there was a considerable scatter in the sputum readings.

The level of penicillin in the sputum was not related to the pathological entity undergoing treatment nor to the stage of the disease.

The presence of penicillinase-producing bacteria in the sputum did not affect the level of penicillin in the sputum.

The number of specimens examined from patients receiving 2 or 3 mega units penicillin per dose was low, but there was a suggestion that the higher doses resulted in a higher sputum level.

The authors wish to thank Professor John W. Crofton, Professor Robert Cruickshank, and Dr. J. C. Gould for their help and advice, Mrs. M. Torrance for technical assistance, and Miss M. H. Ballantine for secretarial assistance.

The research was supported by generous grants from the Royal Victoria Hospital Tuberculosis Trust, Edinburgh, the Scottish Hospital Endowments Research Trust, and the Wellcome Foundation.

\section{REFERENCES}

Heathcote, A. G. S., and Nassau, E. (1951). Concentraticn of peni-

cillin in the lungs. Lancet, 1, 1255.
Humphrey, J. H., and Jcules, H. (1946). Penicillin inhalaticn in pulmonary disease. Ibid., 2. 221 .

Jensen, S. F., Lund, E., and Marner, I. I.. (1962). The concentration of penicillin in blood, urine and sputum after injection of millionunit doses of G-penicillin (natrium benzyl penicillin). Acta path. microbiol. scand., 55, 79.

Lewis, D. O.. and Pines, A. (1965). Treatment of exacerbations of bronchitis with high dosage penicillin and with penicillin plus streptomycin. In the press.

Mulder, J., Goslings, W. R. O., Van der Plas, M. C., and Lopes Cardozo, P. (1952). Studies on the treatment with antibacterial drugs of acute and chronic mucopurulent bronchitis caused by Hemophilus influenzae. Acta med. scand., 143, 32. 